I J ISSN-0973-1547

DOI: 10.15740/HAS/IJPS/14.1/51-54

Visit us - www.researchjournal.co.in

\title{
ReSEARChArTicle
}

\section{Heterosis for yield components in rice (Oryza sativa L.)}

\author{
S.B. Verma
}

\section{SUMMARY}

Heterosis was estimated as per cent increase or decrease of $F_{1}$ values over either heterobeltiosis and over best variety Sarjoo 52. The relative magnitude of heterosis over better parent and standard variety has been studied for ten characters in twenty four hybrids. The nature and magnitude of heterosis differ from character to character depend upon hybrid combinations. Out of $24 \mathrm{~F}_{1}^{\mathrm{s}}$ fifteen and eleven hybrid exhibited significant positive heserosis over better parent and standard variety for grain yield. The cross IR 58025 A x NDRK 5026 (BP) and PMS 10 A x Swarna (SV) were best hybrids.

Key Words : Heterobeltiosis, Rice, Hybrid yield

How to cite this article : Verma, S.B. (2019). Heterosis for yield components in rice (Oryza sativa L.). Internat. J. Plant Sci., 14 (1): 51-54, DOI: 10.15740/HAS/IJPS/14.1/51-54, Copyright@ 2019: Hind Agri-Horticultural Society.

Article chronicle : Received : 26.10.2018; Revised : 12.12.2018; Accepted : 22.12.2018

\section{AUTHOR FOR CORRESPONDENCE}

S.B. Verma, Department of Genetics and Plant Breeding (Agricutural Botany), Udai Pratap Autonomous College, Varanasi (U.P.) India

Email : sbvermaupc@gmail.com 